\title{
MEASURING AND MODELING THE WATER BALANCE IN LOW-RAINFALL CROPPING SYSTEMS
}

\author{
A. M. Whitbread, M. P. Hoffmann, C. W. Davoren, \\ D. Mowat, J. A. Baldock
}

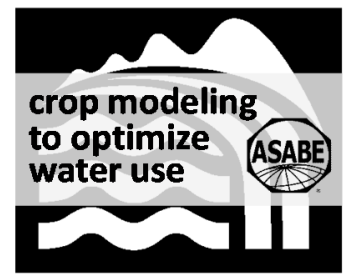

\begin{abstract}
In low-rainfall cropping systems, understanding the water balance, and in particular the storage of soil water in the rooting zone for use by crops, is considered critical for devising risk management strategies for grain-based farming. Crop-soil modeling remains a cost-effective option for understanding the interactions between rainfall, soil, and crop growth, from which management options can be derived. The objective of this study was to assess the error in the prediction of soil water content at key decision points in the season against continuous, multi-layer soil water measurements made with frequency domain reflectometry (FDR) probes in long-term experiments in the Mallee region of South Australia and New South Wales. Field estimates of the crop lower limit or drained upper limit were found to be more reliable than laboratory-based estimates, despite the fact that plant-available water capacity $(P A W C)$ did not substantially differ between the methods. Using the Agricultural Production Systems sIMulator (APSIM) to simulate plant-available water over three-year rotations, predicted soil water was within $7 \mathrm{~mm}$ (PAWC 64 to $99 \mathrm{~mm}$ ) of the measured data across all sowing events and rotations. Simulated $(n=46)$ wheat grain production resulted in a root mean square error $(R M S E)$ of $492 \mathrm{~kg}$ ha-1, which is only marginally smaller than that of other field studies that derived soil water limits with less detailed methods. This study shows that using field-derived data of soil water limits and soil-specific settings for parameterization of other properties that determine soil evaporation and water redistribution enables APSIM to be widely applied for managing climate risk in low-rainfall environments.
\end{abstract}

Keywords. APSIM, Climate risk management, Crop models, Decision support, Soil moisture.

I $\mathrm{n}$ dry environments such as the low-rainfall Mallee region of southeastern Australia (annual rainfall 250 to $350 \mathrm{~mm}$ ), high inherent variability of crop yields caused by seasonal conditions has substantial implications for farm profitability and sustainability. Low-input farming systems, often based on pasture-wheat or fallowwheat rotations were the dominant systems in these regions for decades (Connor, 2004). While these systems were employed to provide fodder, manage root disease risk, mineralize soil nutrients, and in some cases for building up soil water for the cropping phase, such rotations were inherently unsustainable due to the high risk of wind erosion (Leys and McTainsh, 1994) and declines in soil organic carbon (Chan et al., 2003) during fallow phases.

Submitted for review in August 2017 as manuscript number NRES 12581; approved for publication as part of the "Crop Modeling and Decision Support for Optimizing Use of Limited Water" collection by the Natural Resources \& Environmental Systems Community of ASABE in October 2017.

The authors are Anthony M. Whitbread, Soil Scientist, International Crops Research Institute for the Semi-Arid Tropics (ICRISAT), Patancheru, India, CSIRO Agriculture and Food, Waite Campus, Glen Osmond, Australia, and Tropical Plant Production and Agricultural Systems Modeling (TROPAGS), Georg-August-Universität, Göttingen, Germany; Munir P. Hoffmann, Crop Modeler, Tropical Plant Production and Agricultural Systems Modeling (TROPAGS), Georg-August-Universität, Göttingen, Germany; C. William Davoren, Researcher, Damian Mowat, Researcher, and Jeffrey A. Baldock, Soil Scientist, CSIRO Agriculture and Food, Waite Campus, Glen Osmond, Australia. Corresponding author: Anthony M. Whitbread, ICRISAT, Patancheru, 502324 Telangana, India ; phone: +91-40-3071-3071; e-mail: a.whitbread@cgiar.org.
In recent years, more intensive crop rotations based on continuous cropping have been made possible through advances in no-till equipment, increased herbicide options (Llewellyn et al., 2012), and the availability of varieties resistant to cereal cyst nematodes (Vanstone et al., 2008). With water usually being the most limiting resource, the efficient use of rainfall is critical for managing risk (Hoffmann et al., 2017; Hunt et al., 2013; Sadras et al., 2002; Sadras and Angus, 2006; Whitbread et al., 2015). This requires a high level of understanding of the water balance, and in particular the storage of soil water in the rooting zone for use by annual crops. Such information allows, for example, the establishment of robust trigger points for cropping decisions depending on plant-available water (PAW) at critical times in the cropping cycle (Mudge and Whitbread 2010). While in situ measurement of soil water dynamics has been common in the irrigation industry for water scheduling decisions, the cost of sensors has been prohibitive to their widespread use in broadacre applications, so modeling approaches remain a cost-effective option for understanding season and spatial soil water dynamics.

Critical to estimating how much soil water is plant available is the plant-available water capacity (PAWC), as defined by the drained upper limit (DUL), crop lower limit (CLL), and potential rooting depth (Ritchie, 1972a; Ritchie et al., 1999). This information is now widely used to calculate PAW and in water balance modeling with APSIM (Probert et al., 1998; Keating et al., 2003) and DSSAT (Jones et al., 2003). In addition to such parameters, models also re- 
quire other parameters that describe hydraulic properties, including first and second stage evaporation constants, runoff, infiltration, and water movement between layers. Surprisingly, and despite the huge number of studies describing the use of APSIM for Australian (Carberry et al., 2009; Holzworth et al., 2014), African (Whitbread et al., 2010), and other systems, there are limited studies on defining soil parameterization or providing measures of the performance of soil water prediction. This study uses two unique longterm datasets collected in the low-rainfall Mallee region of South Australia and New South Wales to:

1. Compare laboratory and field-based methods for determining PAWC.

2. Test APSIM's soil water balance model, covering periods of fallow and crop growth, to provide estimates of error for soil water and crop yield.

3. Illustrate the potential of water balance modeling to support agronomic and climate risk management.

\section{MATERIALS AND MeTHODS}

Long-term plot-based trials were established at Waikerie in South Australia (34 $17^{\prime} \mathrm{S}, 140^{\circ} 2^{\prime} \mathrm{E}$ ) in 1998 and at Kerribee station near Paringi in New South Wales $\left(34^{\circ} 61^{\prime} \mathrm{S}\right.$, $142^{\circ} 22^{\prime} \mathrm{E}$ ) in 2002 to compare the common district farming practices of the time (late 1990s) with alternative practices based on more intensive management of rotations, reduced tillage, and higher fertilizer inputs. From 2002 to early 2005, soil water dynamics were studied in detail with soil water monitoring equipment installed in three treatments and three replicates at both sites. Whitbread et al. (2015) further describes this study.

The climate at both sites is Mediterranean, characterized by hot dry summers and winter-dominant rainfall (table 1). In this region, significant soil drying occurs throughout the year, with pan evaporation exceeding precipitation by a factor of 5 on an annual basis. Growing season rainfall (April through October) on average is only $164 \mathrm{~mm}$ at Waikerie and $172 \mathrm{~mm}$ at Kerribee, with both areas representing areas of the southeastern cropping belt at the limits of cereal production (SILO database; https://www.longpaddock.qld.gov.au/silo/).

The trial site at Waikerie was located on a sandy soil associated with the dune component of the dune/swale system
Table 1. Average growing season (April through October) and annual climate data for Waikerie and Kerribee, Australia (1900-2008) (https://www.longpaddock.qld.gov.au/silo/). Values in parentheses are standard deviations.

\begin{tabular}{lcc}
\hline \multicolumn{1}{c}{ Climate Parameter } & Waikerie & Kerribee \\
\hline Air temperature $\left({ }^{\circ} \mathrm{C}\right)$ & & \\
Growing season maximum & $19.8(0.1)$ & $19.5(0.1)$ \\
Growing season minimum & $7.1(0.1)$ & $7.1(0.1)$ \\
Annual maximum & $24.0(0.1)$ & $24.1(0.1)$ \\
$\quad$ Annual minimum & $9.8(0.1)$ & $10.4(0.1)$ \\
\hline Rainfall $(\mathrm{mm})$ & & \\
$\quad$ Growing season & $164(5.6)$ & $172(5.9)$ \\
$\quad$ Annual & $255(7.8)$ & $273(8.7)$ \\
\hline Pan evaporation $(\mathrm{mm})$ & & \\
$\quad$ Growing season & $630(3.6)$ & $707(4.5)$ \\
Annual & $1781(6.8)$ & $2016(9.4)$ \\
\hline Solar radiation $\left(\mathrm{MJ} \mathrm{m}^{-2}\right)$ & & \\
$\quad$ Growing season & $2881(10.1)$ & $2971(11.2)$ \\
$\quad$ Annual & $6478(16.9)$ & $6645(18.4)$ \\
\hline
\end{tabular}

typical of the northern Mallee environment and classified as endohypersodic regolithic Hypercalcic Calcarosol (Isbell, 1996). The trial site at Kerribee was situated on a flat swale between low dunes, and the soil was classified as epibasic pedal Calcic Calcarosol. Prior to these trials being established, the sites had been part of a cereal-pasture or cerealfallow based farming operation for several decades after being cleared of the original Mallee vegetation. The major features of these Calcarosols include high sand content throughout the profile, very low organic $\mathrm{C}$ and $\mathrm{N}$ concentrations and low exchangeable cations, and increasing $\mathrm{pH}$ down the profile. The electrical conductivity $(\mathrm{EC})$, chloride $(\mathrm{Cl})$, boron (B), and exchangeable sodium percentage (ESP) increase to extreme levels below the $0.6-0.8 \mathrm{~m}$ depth (table 2 ). The implications of these soil characteristics for PAWC are discussed in the Results section.

At both sites and in the month before the first trial crops, soil from intact and augured samples was collected from several points within the plot areas ( 3 treatments $\times 3$ replicates $\times 6$ depths), bulked, and analyzed for organic and inorganic $\mathrm{C}$, electrical conductivity (EC), and a range of soil physical and textural characteristics. Additionally, pH, B, and exchangeable cations were measured on composite soil samples mixed from three samples collected in the profile of a pit dug adjacent to the sites for soil classification purposes. The analytical techniques were as follows. Organic $\mathrm{C}$ was measured using combustion after pretreatment with dilute

Table 2. Soil physical and chemical properties at the Kerribee and Waikerie experimental sites. Standard errors for values with multiple measures $(\boldsymbol{n}=9)$ are given in parentheses.

\begin{tabular}{|c|c|c|c|c|c|c|c|c|c|c|c|c|c|c|c|}
\hline \multirow{2}{*}{$\begin{array}{l}\text { Depth } \\
(\mathrm{m})\end{array}$} & \multicolumn{3}{|c|}{ Soil Texture $\left(\mathrm{g} \mathrm{kg}^{-1}\right)$} & \multirow{2}{*}{$\begin{array}{c}\text { Inorganic } \\
\mathrm{C} \\
\left(\mathrm{g} \mathrm{kg}^{-1}\right) \\
\end{array}$} & \multirow{2}{*}{$\begin{array}{c}\text { Organic } \\
\mathrm{C} \\
\left(\mathrm{g} \mathrm{kg}^{-1}\right) \\
\end{array}$} & \multirow{2}{*}{$\begin{array}{c}\text { Total } \\
\mathrm{N} \\
\left(\mathrm{g} \mathrm{kg}^{-1}\right) \\
\end{array}$} & \multirow{2}{*}{$\begin{array}{c}\mathrm{EC} \\
\left(\mathrm{dS} \mathrm{m}^{-1}\right) \\
\end{array}$} & \multirow[b]{2}{*}{$\mathrm{pH}_{\mathrm{W}}$} & \multirow[b]{2}{*}{$\mathrm{pH}_{\mathrm{Ca}}$} & \multirow{2}{*}{$\begin{array}{c}\mathrm{B} \\
\left(\mathrm{mg} \mathrm{kg}^{-1}\right) \\
\end{array}$} & \multicolumn{4}{|c|}{$\begin{array}{l}\text { Exchangeable Cations } \\
(\text { meq per } 100 \mathrm{~g})\end{array}$} & \multirow{2}{*}{$\begin{array}{l}\text { ESP } \\
(\%)\end{array}$} \\
\hline & Clay & Silt & Sand & & & & & & & & $\mathrm{Ca}^{++}$ & $\mathrm{Mg}^{++}$ & $\mathrm{Na}^{+}$ & $\mathrm{K}^{+}$ & \\
\hline \multicolumn{16}{|l|}{ Kerribee } \\
\hline $0-0.1$ & $106(4)$ & $55(2)$ & $827(6)$ & $0.3(0.0)$ & $6.7(0.2)$ & $0.63(0.01)$ & $0.07(0.01)$ & 7.9 & 7.1 & 3.8 & 10.1 & 0.8 & 0.04 & 0.8 & 0.3 \\
\hline $0.1-0.2$ & $152(7)$ & $62(3)$ & $771(9)$ & $0.9(0.3)$ & $5.1(0.2)$ & $0.44(0.02)$ & $0.10(0.01)$ & 8.5 & 7.8 & - & - & - & - & - & - \\
\hline $0.2-0.4$ & $177(11)$ & $61(3)$ & $725(14)$ & $3.1(1.1)$ & $4.0(0.3)$ & $0.37(0.02)$ & $0.10(0.00)$ & 8.8 & 8.0 & 2 & 10.2 & 1.2 & 0.04 & 0.5 & 0.3 \\
\hline 0.4-0.6 & $219(47)$ & $47(4)$ & $639(19)$ & $11.3(1.6)$ & $3.0(0.3)$ & $0.28(0.01)$ & $0.13(0.01)$ & 9.1 & 8.2 & 1.9 & 7.5 & 1.9 & 0.07 & 0.3 & 0.7 \\
\hline $0.6-0.8$ & $242(41)$ & $41(3)$ & $581(7)$ & $20.8(1.0)$ & $2.5(0.5)$ & $0.18(0.01)$ & $0.23(0.01)$ & 9.7 & 8.4 & 7.0 & 7.3 & 4.5 & 1.91 & 1.3 & 12.8 \\
\hline $0.8-1.0$ & $221(41)$ & $41(2)$ & $596(10)$ & $22.5(1.5)$ & $3.8(0.5)$ & $0.12(0.01)$ & $0.38(0.02)$ & 10.1 & 8.5 & 15.0 & 7.4 & 4.9 & 5.7 & 2.2 & 28.3 \\
\hline \multicolumn{16}{|l|}{ Waikerie } \\
\hline $0-0.1$ & $71(2)$ & $15(3)$ & 918 (3) & $0.1(0.1)$ & $6.1(0.3)$ & $0.44(0.02)$ & $0.06(0.01)$ & 8.0 & 7.2 & 1.1 & 8.6 & 2.3 & 0.10 & 1.9 & 0.8 \\
\hline $0.1-0.2$ & $70(4)$ & $11(4)$ & $920(8)$ & $0.5(0.3)$ & $3.4(0.4)$ & $0.16(0.02)$ & $0.06(0.01)$ & 9.0 & 8.1 & 1.5 & 8.4 & 2.1 & 0.10 & 1.5 & 0.8 \\
\hline $0.2-0.4$ & $70(4)$ & $16(3)$ & 909 (11) & $1.6(0.6)$ & $2.3(0.6)$ & $0.12(0.02)$ & $0.07(0.01)$ & 9.2 & 8.3 & 1.4 & 9.7 & 2.4 & 0.10 & 1.0 & 0.8 \\
\hline $0.4-0.6$ & $73(5)$ & $15(3)$ & $901(10)$ & $2.9(1.0)$ & $1.1(0.2)$ & $0.08(0.01)$ & $0.08(0.01)$ & 9.3 & 8.4 & 1.1 & 10.0 & 6.1 & 1.00 & 0.6 & 5.6 \\
\hline $0.6-0.8$ & $105(9)$ & 27 (4) & 804 (30) & $8.7(2.5)$ & $0.4(0.1)$ & $0.07(0.01)$ & $0.18(0.03)$ & 9.7 & 8.5 & 6.5 & 5.0 & 7.0 & 2.90 & 0.6 & 18.7 \\
\hline 0.8-1.0 & $153(9)$ & $29(4)$ & $674(42)$ & $18.4(4.4)$ & $0.3(0.1)$ & $0.06(0.01)$ & $0.37(0.05)$ & 10.1 & 8.6 & 21.0 & 3.1 & 7.6 & 5.30 & 0.9 & 31.4 \\
\hline
\end{tabular}


acid to remove inorganic $\mathrm{C}$. Inorganic $\mathrm{C}$ was measured using the rapid titration method, as described by Rayment and Lyons (2011). Soil pH (water) and EC was measured with a $\mathrm{pH} / \mathrm{EC}$ meter on a 1:5 soil:water extracts. For soil $\mathrm{pH}$ $\left(\mathrm{CaCl}_{2}\right)$, measurement was made on a 1:5 soil: $\mathrm{CaCl}_{2}$ extract. Chloride was measured colormetrically on 1:5 soil:water extracts but is not reported because the concentrations were low and $<18 \mathrm{mg} \mathrm{kg}^{-1}$ at all depths. Soluble B was determined using $0.01 \mathrm{M} \mathrm{CaCl}_{2}$ extracting solution for $10 \mathrm{~min}$ (Rayment and Higginson, 1992). Samples were immersed in a water bath $\left(98^{\circ} \mathrm{C}\right)$, and the extracts were filtered hot and analyzed using ICP-OES. Soil textural analysis of the proportions of sand, silt, and clay was performed using the pipette method after sieving to remove gravel, as described by Hutton (1955) and USDA (1982). Cation exchange capacity (CEC) was determined using $1 \mathrm{M}$ ammonium chloride following pretreatment for soluble salts, as described by Rayment and Lyons (2011).

In the days prior to sowing and following harvest, a selection of treatments and all replicates were sampled at six soil depth layers $(0-0.1 \mathrm{~m}, 0.1-0.2 \mathrm{~m}, 0.2-0.4 \mathrm{~m}, 0.4-0.6 \mathrm{~m}$, 0.6-0.8 m, and 0.800-1.0 m). In the field, soil samples were sealed in plastic bags and immediately stored under cool conditions. Upon return to the laboratory, the samples were weighed for field moisture content, divided in half, and then dried at $105^{\circ} \mathrm{C}$ for $48 \mathrm{~h}$ for dry weight determination. Mineral $\mathrm{N}\left(\mathrm{NH}_{4}\right.$ and $\left.\mathrm{NO}_{3}\right)$ was determined on field-moist soil samples after extraction with $1 \mathrm{M} \mathrm{KCl}$, with the filtrate analyzed using the Kjeldahl procedure (Rayment and Lyons, 2011).

\section{Management OF Trials}

Field trials were established at Waikerie in 1998 and at Kerribee in 2002 with eleven treatments representing a range of possible rotation systems. Whitbread et al. (2015) presented the results from many of these treatments; however, in this study, detailed monitoring of soil water dynamics was confined to three treatments at each site. At Waikerie, detailed monitoring of soil moisture content using frequency domain reflectometry (FDR) sensors (Dean et al. 1987) was undertaken in wheat-pasture, wheat-fieldpea, and wheatcanola treatments, while at Kerribee the FDR sensors were installed in fallow-wheat, wheat-fallow, and wheat-canola treatments.

At Waikerie, the wheat-pasture rotation (also known as district practice at that time) was a low-input treatment with low fertilizer applied at sowing $\left(5 \mathrm{~kg} \mathrm{~N} \mathrm{ha}^{-1}, 11 \mathrm{~kg} \mathrm{P} \mathrm{ha}^{-1}\right)$ and a wheat sowing rate of $60 \mathrm{~kg} \mathrm{ha}^{-1}$. In this rotation, the pasture phase consists of a range of self-sown forbs/herbs, summer-growing annual grasses, and legumes that may emerge in response to rainfall. These pastures are typically grazed with sheep, although in this trial grazing occurred infrequently. At the end of the pasture phase, typically early summer, cultivation was used to control weeds in preparation for the cereal phase, with up to four cultivations occurring over summer and early spring prior to sowing. At Kerribee, the fallow-wheat or wheat-fallow treatments, also representing the district practice, was that of cultivated (and/or sprayed) fallow-wheat with low fertilizer inputs at sowing $\left(6 \mathrm{~kg} \mathrm{~N} \mathrm{ha}^{-1}, 13 \mathrm{~kg} \mathrm{P} \mathrm{ha}^{-1}\right)$ and a wheat sowing rate of $20 \mathrm{~kg}$ $\mathrm{ha}^{-1}$. Knockdown herbicide (glyphosate) and cultivations were used to control weeds during the fallow phase.

The continuous cropping treatments include a wheat-canola and wheat-field pea rotation at Waikerie and a wheatcanola rotation at Kerribee. These treatments were under notill management and therefore were never cultivated, with all residue from the previous crop remaining on the surface and weed control based entirely on herbicide use. These treatments received higher fertilizer inputs $\left(27 \mathrm{~kg} \mathrm{~N} \mathrm{ha}^{-1}, 16.5 \mathrm{~kg}\right.$ $\mathrm{P} \mathrm{ha}^{-1}$ ) than the district practice, with all fertilizer applied at seeding at fixed annual rates.

Sowing of all crops was in response to the break of the season (usually early May to late June) using a sowing unit with narrow points followed by press wheels. In-crop management was mainly concerned with controlling weeds using selective herbicides or hand weeding and monitoring for root disease. Grain harvests took place after physiological maturity in the period from mid-November to late December using a plot harvester. Approximately $3 \mathrm{~m}$ at each end of the plot was removed, with the remaining $44 \mathrm{~m}$ of plot harvested for grain. Grain yields are reported as field-weighed moisture content $(\sim 13 \%)$.

\section{Measurement of Soil Hydraulic Properties}

A comparison was undertaken of the common field and laboratory methods used to determine approximations of soil moisture content at DUL and CLL, which then define the soil's PAWC. DUL was measured using a single $4 \mathrm{~m} \times 4 \mathrm{~m}$ pond area set up adjacent to the trials following the methodology described by Dalgliesh and Foale (1998). CLL was defined as the minimum volumetric water content reached during the period of active plant growth between 1 August and two weeks before harvest and was estimated from the FDR dataset.

To monitor soil water dynamics, FDR probes (CS615, Campbell Scientific) were installed at six depths in the center of plots of three treatments $\times$ three replicates. At Waikerie, FDR probes were installed in wheat-fallow, wheatfield pea, and wheat-canola treatments in late 1998. At Kerribee, FDR probes were installed in fallow-wheat, wheat-fallow, and wheat-canola treatments. The $15 \mathrm{~cm}$ long probes were installed into predrilled guide holes at a $45^{\circ}$ angle into the middle of each soil depth layer (0-0.1 m, 0.1-0.2 m, 0.20$0.4 \mathrm{~m}, 0.4-0.6 \mathrm{~m}, 0.6-0.8 \mathrm{~m}$, and 0.8-1.0 m). These buried sensors were connected to data loggers and measured hourly. The data presented in this article are the 12:00 $\mathrm{h}$ readings collected continuously from 1 January 2002 to 31 December 2004 at Waikerie and from 24 April 2002 to 31 December 2004 at Kerribee. This period of measurement covers three cropping seasons and is a virtually uninterrupted dataset. Sadras et al. (2003) reported on a limited quantity of soil water data collected at Waikerie from February 1999 to March 2002. For each sensor, the acquired FDR data were converted to soil volumetric water content using calibration equations derived from the actual soil volumetric water content data measured from core samples collected throughout the duration of the project to cover a range of soil water contents.

From additional intact soil cores collected from three treatments within the experimental area (three replicates), a 
suction plate apparatus was used to determine the volumetric water content of each layer at $-10 \mathrm{kPa}\left(\theta_{\mathrm{v} 10}\right)$ and $-1500 \mathrm{kPa}$ $\left(\theta_{\mathrm{v} 1500}\right)$. For these same samples, the air-dried volumetric moisture content $\left(\theta_{\mathrm{VAD}}\right)$ was determined after oven drying at $40^{\circ} \mathrm{C}$ to constant mass. The following is a summary of the data presented in this article:

$\theta_{\mathrm{vDUL}}=$ volumetric water content at drained upper limit.

$\theta_{\mathrm{vCLL}}=$ volumetric water content at crop lower limit.

$\theta_{\mathrm{vAD}}=$ volumetric water content after drying at $40^{\circ} \mathrm{C}$ to constant mass.

$\theta_{\mathrm{v} 10}=$ volumetric water content at $-10 \mathrm{kPa}$ matric potential.

$\theta_{\mathrm{v} 1500}=$ volumetric water content at $-1500 \mathrm{kPa}$ matric potential.

$\theta_{\mathrm{vSAT}}=$ water content at saturation calculated from total porosity -0.05 , where total porosity is calculated as:

$\mathrm{TP}=1$ - bulk density/particle size density

and particle size density is assumed to be $2.65 \mathrm{~g} \mathrm{~cm}^{-3}$.

PAWC = plant-available water capacity, which is difference between the total available water $(0$ to $1.0 \mathrm{~m})$ at $\theta_{\mathrm{vDUL}}$ and $\theta_{\mathrm{vCLL}}$ (Dalgliesh and Foale, 1998).

\section{Modeling THE Crop-SoIL SySTEM}

APSIM (Keating et al., 2003; Holzworth et al., 2014) simulates crop growth and its interactions with daily temperature, radiation, rainfall, and some of the major soil processes (i.e., nitrogen and carbon dynamics and water balance, including evaporation, drainage, leaching, and runoff). For comparing the measured and modeled soil water data, the crop-soil model APSIM v7.5 (www.apsim.info) was used to simulate the crop-soil system in the three treatments and assess the reliability of the simulations against the measured yield data.

To simulate the crop-soil system in the three treatments (averaged over three replicates) for which FDR data were available, the simulations were initialized to the measured soil water content (1 January 2002 at Waikerie, 24 April 2002 at Kerribee) and run continuously without further soil water reset until 19 April 2005. Additionally, simulations were designed to evaluate the sensitivity of the soil hydraulic parameterizations on the prediction of soil water and yield of the continuously cropped treatments at both sites. The laboratory-measured values of DUL and CLL (alternatively represented by laboratory-measured values of $\theta_{\mathrm{v} 10}$ and $\theta_{\mathrm{v} 1500}$, respectively) were tested in the following combinations: $\theta_{\mathrm{vCLL}}$ and $\theta_{\mathrm{v} 10}, \theta_{\mathrm{v} 1500}$ and $\theta_{\mathrm{vDUL}}$, and $\theta_{\mathrm{v} 1500}$ and $\left.\theta_{\mathrm{v} 10}\right)$. All other parameters remained constant.

To assess the reliability of the simulations against the measured yield data, all treatments described previously and additional rotation treatments described by Whitbread et al. (2015) were considered $(n=46)$. Simulations for Waikerie began on 1 January 1998, initialized to soil water and mineral $\mathrm{N}$ and $\mathrm{C}$ values measured prior to the 1998 treatment (pasture or wheat), and then run continuously without reset of water until 31 December 2008. Simulated soil mineral N content was underestimated in the long-term runs and was therefore reset to values measured at sowing for each crop (Whitbread et al., 2015). In the pasture years of the district practice treatments, to represent the likely growth and water use of volunteer pasture and weeds, the sowing of a shortduration winter dicot was triggered following the first substantial rain in April or May. This volunteer pasture was terminated on 1 November. The procedure was similar for the three Kerribee treatments except that the trial period was shorter, and simulations started on 1 January 2002 and terminated on 31 December 2008. Management processes, such as sowing and tillage operations, were implemented in the operations menu for the date on which the operation took place.

A further simulation study was designed to simulate continuous wheat treatments at Waikerie, from which the effects of planting date and stored soil water content could be assessed similar to Mudge and Whitbread (2010). Long-term simulations (1900-2008) were initialized to soil water and mineral $\mathrm{N}$ and $\mathrm{C}$ values measured in the Waikerie trial (1998 values; Whitbread et al., 2015) and run continuously, resetting only soil mineral $\mathrm{N}$ and crop residues before sowing annually. Planting was based on a rule-based trigger, with wheat cultivar Yitpi sown between 15 April and 15 July when $15 \mathrm{~mm}$ or more rainfall was received. An application of $5 \mathrm{~kg} \mathrm{~N} \mathrm{ha}^{-1}$ was applied as urea at sowing. In the event that sowing was not triggered, sowing took place on the last day of the sowing window (15 July). The simulated crop was harvested at maturity, and outputs (grain yield, in-crop rainfall, and PAW at sowing) were collated and analyzed.

\section{Parameterization for All Simulations}

Daily climatic records (maximum and minimum temperatures, rainfall) for the duration of the experiments were measured at the experimental sites. Longer-term weather data and solar radiation data were obtained from the closest and most reliable weather datasets obtained from the SILO database (https://www.longpaddock.qld.gov.au/silo/). The Waikerie simulations used the Waikerie data (Station 024018, $\sim 5 \mathrm{~km}$ from the site), and the Kerribee simulations used the Mildura Post Office data (Station 076077, $\sim 15 \mathrm{~km}$ from the site).

The soil water balance uses a cascading water balance model (SoilWat), described in detail by Probert et al. (1998). Maximum rooting depth of wheat at both sites was $1.5 \mathrm{~m}$ (1.0 $\mathrm{m}$ for canola), while at Waikerie where fieldpeas were grown, rooting depth was restricted to $0.6 \mathrm{~m}$.

Rainfall infiltration was calculated using the USDA-SCS curve number technique (Rallison, 1980) and was set to 80 at both sites. Soil evaporation $\left(E_{s}\right)$ was based on the twostage model described by Ritchie (1972b). First-stage evaporation $\left(U, \mathrm{~mm} / \mathrm{t}^{1 / 2}\right)$ comes into effect soon after a recharge event when the soil is wet enough for water to be transported to the surface at a rate equal to the potential evaporation rate. This rate is calculated using an equilibrium evaporation concept as modified by Priestley and Taylor (1972). When the water content of the soil has decreased to below this threshold value, represented by $U$, the rate of supply from the soil, as determined by the diffusivity settings of constant and slope (table 3 ) will be less than the potential evaporation, and this is termed second-stage evaporation (Cona, $\mathrm{mm} / \mathrm{t}^{1 / 2}$ ). Water lost by evaporation is removed from the surface layer, and this layer can dry below CLL to an estimate of the air- 
Table 3. APSIM parameter settings for modeling water balance.

\begin{tabular}{cccccc}
\hline Site & CN2Bare & $\begin{array}{c}\text { Diffusivity } \\
\text { Constant }\end{array}$ & $\begin{array}{c}\text { Diffusivity } \\
\text { Slope }\end{array}$ & $U$ & Cona \\
\hline Waikerie & 80 & 250 & 22 & 4 & 2 \\
Kerribee & 80 & 88 & 35 & 4 & 3 \\
\hline
\end{tabular}

dry water content (table 3 ). The parameter settings for firststage $(U)$ and second-stage (Cona) evaporation, diffusivity (movement of water up and down the profile), and the runoff curve number for bare soil (CN2) have been found to be particularly important for accurately modeling of the water balance in low-rainfall regions (Whitbread et al., 2008). The $U$ and Cona parameters were adjusted from the default values suggested by Yunusa et al. (2004) for a red-brown earth soil at Roseworthy, South Australia (i.e., $U=4.7 \mathrm{~mm}$, Cona $=$ $4 \mathrm{~mm}^{1 / 2}$ ) to values that best match the measured soil water dynamics (first-stage and second-stage evaporation) during large rainfall events in a period of no crop growth (table 3 ). These settings match those for a similarly textured soil described by Mudge and Whitbread (2010) but are higher than the $U$ and Cona settings that Hunt and Kirkegaard (2011) used to model sandy soil types (i.e., $U=2 \mathrm{~mm}$, Cona = $\left.2 \mathrm{~mm}^{1 / 2}\right)$. An approach for deriving these settings based on texture, as suggested by Ritchie and Crum (1989), was not applicable.

\section{Statistical Analysis}

To assess the goodness of fit of the simulated and measured comparisons, the root mean square error (RMSE) between the predicted and observed data was calculated as:

$$
\operatorname{RMSE}=\left[\left(\sum(O-P)^{2} / n\right)\right]^{0.5}
$$

where $O$ and $P$ are paired observed and predicted data, and $n$ is the number of observations. Regression analysis was carried out to investigate the relationship between predicted and simulated wheat yields and the soil moisture on the days of sowing and harvest.

\section{RESULTS}

Defining SoIl Water Limits and PlantAvailable SoIl Water CaPaCiTy

At Waikerie, the $\theta_{\mathrm{v} 10}$ values in the $0-0.1 \mathrm{~m}, 0.1-0.2 \mathrm{~m}$, 0.4-0.6 $\mathrm{m}$, and 0.8-1.0 $\mathrm{m}$ layers were well above the maximum soil moisture content recorded with the FDR probes (table 4), while the $\theta_{\mathrm{vDUL}}$ values were just below the peak FDR soil moistures that coincided with the larger rainfall events (figs. 1a to 1d). Conversely, at Kerribee, $\theta_{\mathrm{vDUL}}$ was always higher than the $\theta_{\mathrm{v} 10}$ measurements, with the exception of the 0.8-1.0 m layer (table 4). In the two deepest layers at Kerribee, the FDR-measured soil moisture never exceeded the upper limits measured by $\theta_{\mathrm{v} 10}$ or $\theta_{\mathrm{vDUL}}$, reflecting that these layers remained relatively dry throughout the measurement period. The calculated $\theta_{\mathrm{VSAT}}$ values at both sites far exceeded all FDR $\theta_{\mathrm{v}}$ measurements made in this period (table 4).

\section{Lower Limits}

At Waikerie, in the top four layers, the $\theta_{\mathrm{v} 1500}$ was always higher and did not correlate well with the FDR moisture contents measured around maturity (table 4 ). In the $0.6-0.8 \mathrm{~m}$ layer, $\theta_{\mathrm{v} 1500}$ was far below any field-measured values; however, in the $0.80-1.0 \mathrm{~m}$ layer, there was a reasonable correlation with measured lower limits. At Kerribee, $\theta_{\mathrm{v} 1500}$ was close to $\theta_{\mathrm{vLL}}$ (wheat) estimated from the FDR data in the 0.1$0.2 \mathrm{~m}$ and 0.4-0.6 m layers and deeper. Interestingly, total soil water storage to $1 \mathrm{~m}$ calculated from the $\theta_{\mathrm{v} 1500}$ or FDR $\theta_{\mathrm{vLL}}$ (wheat) differed by $4 \mathrm{~mm}$ or less at both sites. This result is of little consequence, as the soil water limits varied dramatically between methods in the individual layers, with the distribution of soil moisture in the profile an important factor for access by plant roots. Using $\theta_{\mathrm{vDUL}}$ and $\theta_{\mathrm{vLL}}$ as the upper and lower limits, respectively, PAWC was defined. Because the soil at Waikerie contained more sand and less clay and silt-sized particles at all depths in the profile than the Kerribee soil (table 2), it held less water at $\theta_{\mathrm{vDUL}}$ and at $\theta_{\mathrm{vCLL}}$ (table 4). At Waikerie, PAWC was therefore calculated

Table 4. Properties of the Kerribee and Waikerie experimental sites related to soil water holding capacity. Lower limits determined for wheat (W), fieldpea (FP), and canola (C). Standard errors for data measured on multiple samples $(n=3)$ are given in parentheses.

\begin{tabular}{|c|c|c|c|c|c|c|c|c|c|c|}
\hline \multirow{2}{*}{$\begin{array}{c}\text { Depth } \\
(\mathrm{m})\end{array}$} & \multirow{2}{*}{$\begin{array}{c}\mathrm{BD} \\
\left(\mathrm{g} \mathrm{cm}^{-3}\right)\end{array}$} & \multirow{2}{*}{$\begin{array}{c}\theta_{\mathrm{VSAT}} \\
\left(\mathrm{mm} \mathrm{mm}^{-1}\right)\end{array}$} & \multirow{2}{*}{$\begin{array}{c}\theta_{\mathrm{vDUL}} \\
\left(\mathrm{mm} \mathrm{mm}^{-1}\right)\end{array}$} & \multirow{2}{*}{$\begin{array}{c}\theta_{\mathrm{vAD}} \\
\left(\mathrm{mm} \mathrm{mm}^{-1}\right)\end{array}$} & \multirow{2}{*}{$\begin{array}{c}\theta_{\mathrm{v} 10} \\
\left(\mathrm{~mm} \mathrm{~mm}^{-1}\right)\end{array}$} & \multirow{2}{*}{$\begin{array}{c}\theta_{\mathrm{v} 1500} \\
\left(\mathrm{~mm} \mathrm{~mm}^{-1}\right)\end{array}$} & \multicolumn{4}{|c|}{ FDR Data $\left(\mathrm{mm} \mathrm{mm}^{-1}\right)$} \\
\hline & & & & & & & $\theta_{\mathrm{VCLL}}(\mathrm{W})$ & $\theta_{\mathrm{vLL}}(\mathrm{FP})$ & $\theta_{\mathrm{vLL}}(\mathrm{C})$ & $\theta_{\mathrm{vMax}}$ \\
\hline \multicolumn{11}{|l|}{ Waikerie } \\
\hline $0-0.1$ & $1.52(0.02)$ & 0.373 & $0.080(0.01)$ & 0.004 & $0.145(0.002)$ & $0.039(0.012)$ & 0.020 & 0.023 & 0.023 & 0.122 \\
\hline $0.1-0.2$ & $1.68(0.02)$ & 0.316 & $0.070(0.00)$ & 0.004 & $0.121(0.005)$ & $0.031(0.005)$ & 0.024 & 0.033 & 0.030 & 0.110 \\
\hline $0.2-0.4$ & $1.63(0.01)$ & 0.333 & $0.090(0.01)$ & 0.004 & $0.101(0.002)$ & $0.041(0.007)$ & 0.035 & 0.038 & 0.038 & 0.130 \\
\hline $0.4-0.6$ & $1.60(0.01)$ & 0.345 & $0.100(0.01)$ & 0.004 & $0.132(0.001)$ & $0.055(0.011)$ & 0.042 & 0.047 & 0.045 & 0.111 \\
\hline $0.6-0.8$ & $1.59(0.05)$ & 0.349 & $0.170(0.03)$ & 0.005 & $0.120(0.001)$ & $0.048(0.008)$ & 0.084 & 0.075 & 0.085 & 0.155 \\
\hline $0.8-1.0$ & $1.66(0.02)$ & 0.323 & $0.190(0.02)$ & 0.008 & $0.233(0.004)$ & $0.120(0.014)$ & 0.121 & - & 0.121 & 0.182 \\
\hline$n$ & 6 & 6 & 6 & 9 & 9 & 9 & & & & \\
\hline \multicolumn{2}{|c|}{$\begin{array}{l}\text { Total soil water content } \\
(0-1.0 \mathrm{~m})(\mathrm{mm})\end{array}$} & 339 & 125 & 5 & 144 & 60 & 61 & 38 & 63 & 139 \\
\hline \multicolumn{11}{|l|}{ Kerribee } \\
\hline $0-0.1$ & $1.29(0.02)$ & 0.465 & $0.128(0.001)$ & 0.008 & $0.084(0.004)$ & 0.054 & 0.028 & - & - & 0.207 \\
\hline $0.1-0.2$ & $1.53(0.02)$ & 0.373 & $0.170(0.004)$ & 0.009 & $0.123(0.007)$ & 0.056 & 0.065 & - & - & 0.183 \\
\hline $0.2-0.4$ & $1.44(0.02)$ & 0.406 & $0.186(0.001)$ & 0.012 & $0.150(0.010)$ & 0.063 & 0.100 & - & - & 0.167 \\
\hline $0.4-0.6$ & $1.49(0.03)$ & 0.389 & $0.216(0.003)$ & 0.014 & $0.192(0.015)$ & 0.103 & 0.105 & - & - & 0.192 \\
\hline $0.6-0.8$ & $1.57(0.03)$ & 0.357 & $0.223(0.002)$ & 0.012 & $0.219(0.014)$ & 0.119 & 0.110 & - & - & 0.202 \\
\hline $0.8-1.0$ & $1.63(0.02)$ & 0.337 & $0.212(0.009)$ & 0.009 & $0.238(0.015)$ & 0.132 & 0.110 & - & - & 0.185 \\
\hline$n$ & 3 & 3 & 3 & 9 & 9 & 1 & & & & \\
\hline \multicolumn{2}{|c|}{$\begin{array}{l}\text { Total soil water content } \\
(0-1.0 \mathrm{~m})(\mathrm{mm})\end{array}$} & 381 & 197 & 11 & 181 & 94 & 98 & - & - & 188 \\
\hline
\end{tabular}




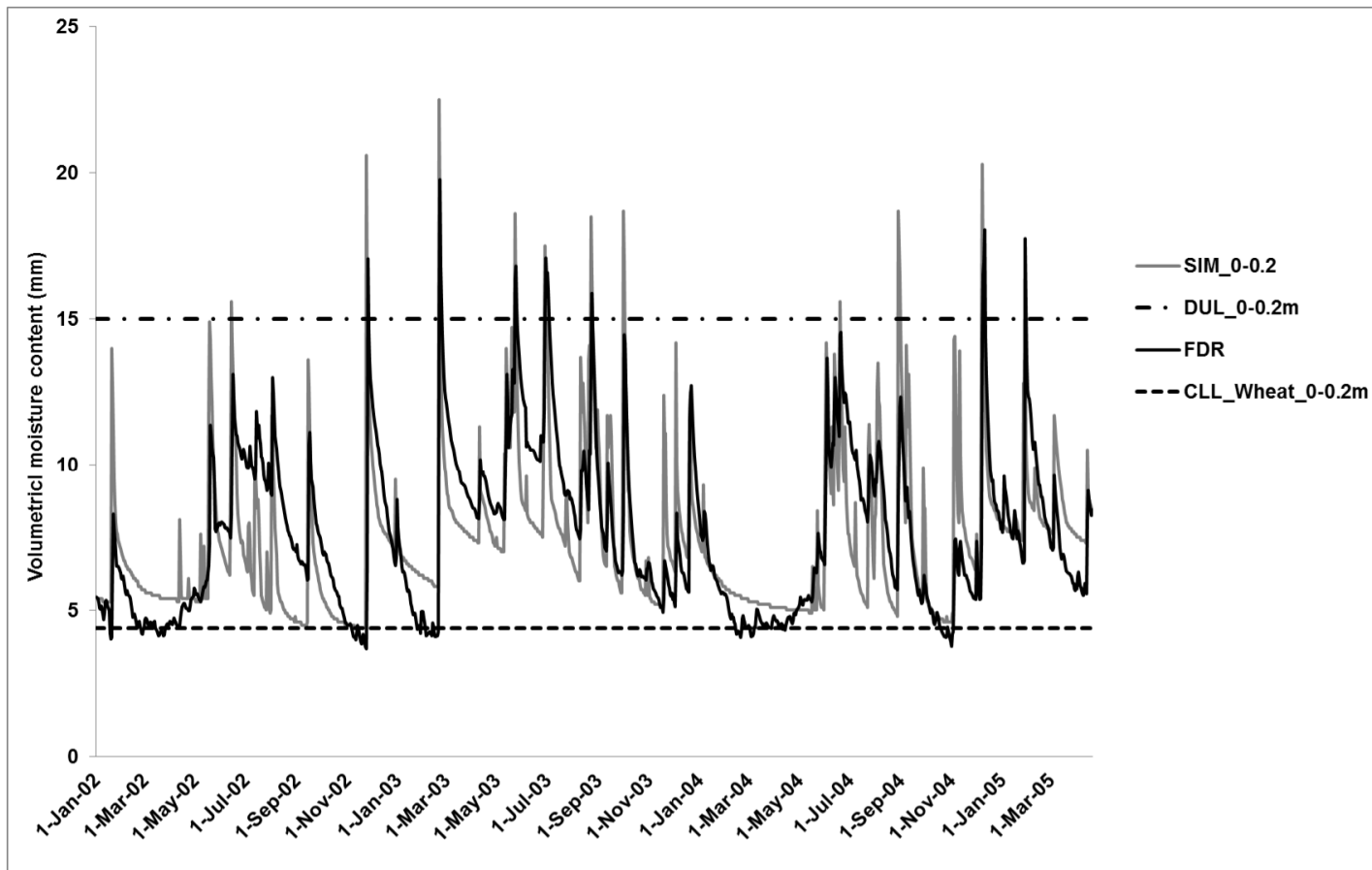

Fig. 1a

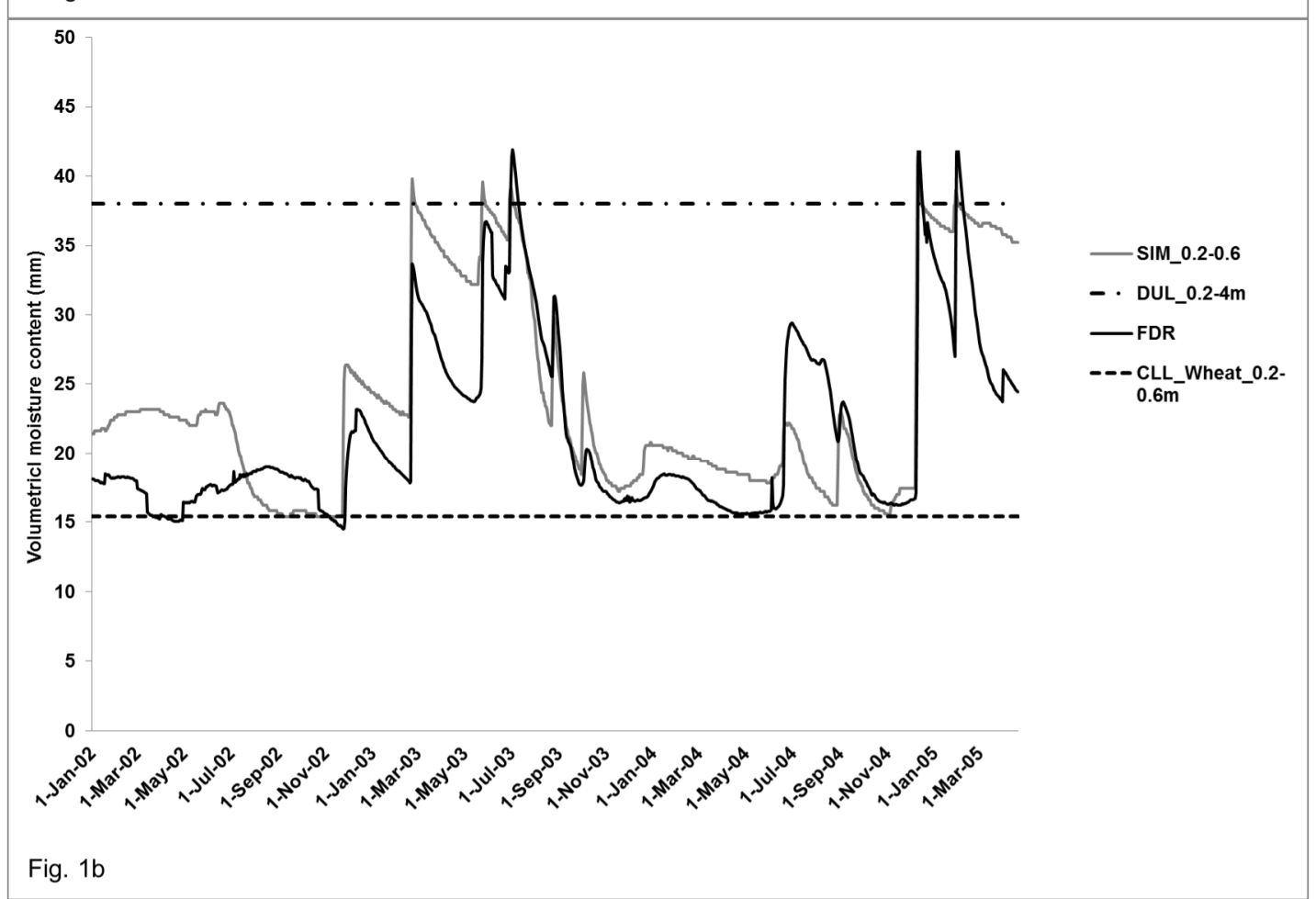

Figure 1. Measured and simulated soil water content (mm) calculated for the (a) 0-0.2 m layer and (b) 0.2-0.6 m layer for Waikerie treatment 9 (wheat-canola-wheat) during 2002 to 2005.

as 64 and $62 \mathrm{~mm}$ for wheat and canola, respectively $(0-1.0 \mathrm{~m})$ and $49 \mathrm{~mm}$ for field peas $(0-0.8 \mathrm{~m})$. At Kerribee, PAWC of $99 \mathrm{~mm}$ was determined for the CLL of wheat.

\section{Model Performance}

\section{Measured versus Modeled Soil Moisture}

At Waikerie, comparison of the FDR $\theta_{\mathrm{v}}$ data and the modeled water balance data was undertaken for the 0-0.2 m, 0.2-
$0.6 \mathrm{~m}$, and 0.6-1.0 m layers (figs. $1 \mathrm{a}, 1 \mathrm{~b}$, and $1 \mathrm{c}$, respectively) and for total water content (0-1.0 m) (fig. 1d) using the continuous cropping treatment (wheat-canola-wheat). The pooling of data was considered necessary, especially for the 0-0.1 $\mathrm{m}$ and 0.1-0.2 $\mathrm{m}$ layers where the time-step difference between modeled and simulated water dynamics was smoothed by expressing the total water content over a larger 


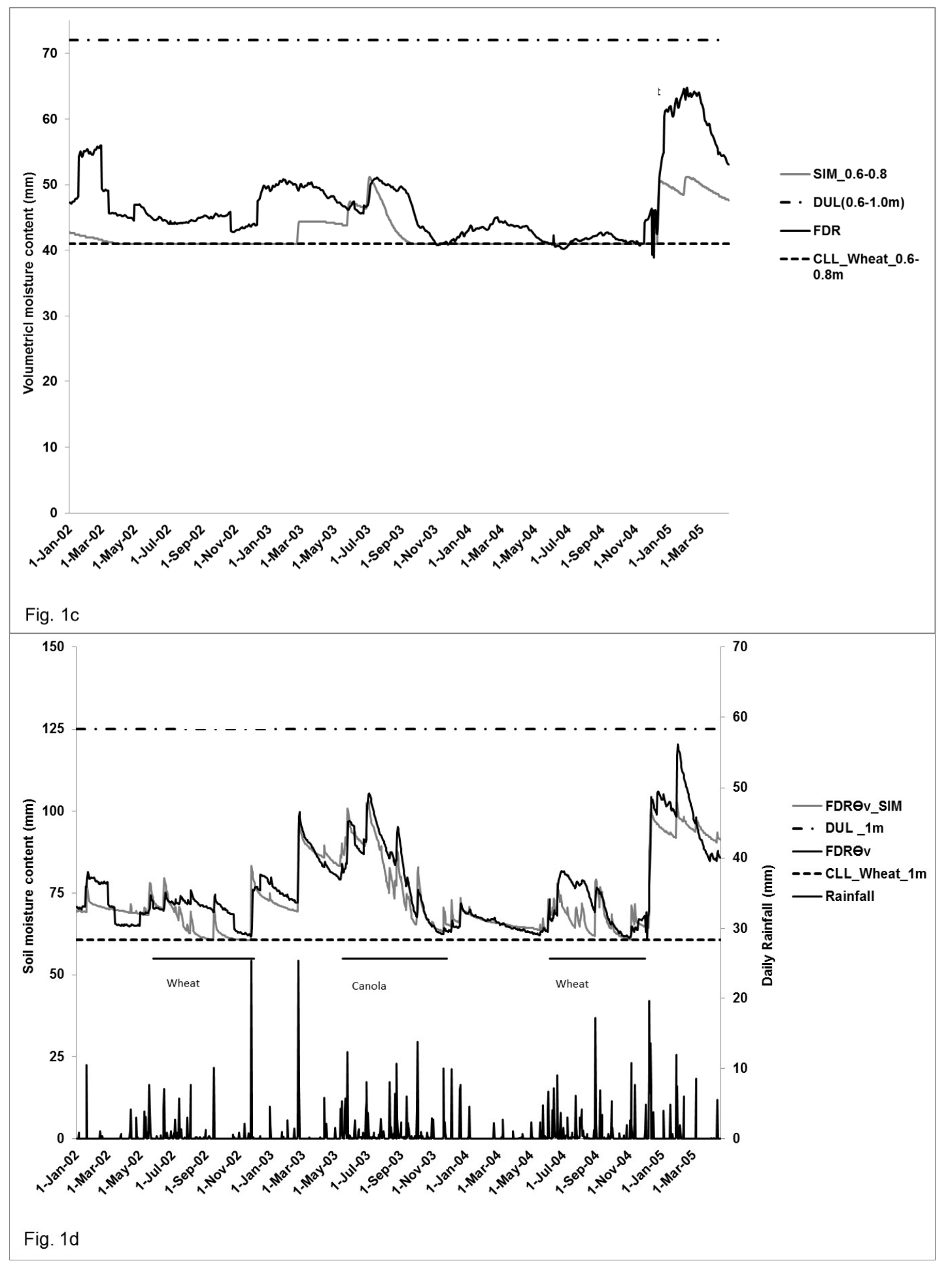

Figure 1 (continued). Measured and simulated soil water content $(\mathrm{mm})$ calculated for the (c) 0.6-1.0 $\mathrm{m}$ layer and (d) 0-1.0 $\mathrm{m}$ profile for Waikerie treatment 9 (wheat-canola-wheat) during 2002 to 2005. Figure 1d also displays daily rainfall data, and the horizontal lines represent the growing season (sowing to harvest) for each crop.

depth. Furthermore, this dataset was chosen because a crop was planted in each season, and therefore the effects of weeds on the water balance during the winter season were minimized. Multi-species weed populations are difficult to simulate accurately, and the validation data were not detailed enough to enable this to be undertaken. The $\theta_{\mathrm{vDUL}}$ and $\theta_{\mathrm{vLL}}$ (wheat) for these combined layers were also displayed to indicate the PAW range. There were excellent correlations be- tween the measured and modeled soil water data at all depths, with some exceptions (table 5). In the first six months of measurement (January to June 2002), the simulated water content in the 0-0.2 $\mathrm{m}$ and 0.2-0.6 m layers was overestimated, while it was at times underestimated in the deepest layer $(0.6-1.0 \mathrm{~m})$. Combining the data in figure $1 \mathrm{~d}$ hides this fact, as the differences average out to some extent. This overestimation of water content in the upper two com- 
Table 5. Comparison of methodologies used to define upper ( $\theta_{\mathrm{vDuL}}$ vs. $\left.\theta_{\mathrm{v} 10}\right)$ and lower $\left(\theta_{\mathrm{vLL}}-\mathrm{wheat}\right.$ vs. $\left.\theta_{\mathrm{v} 1500}\right)$ limits of soil water as assessed by goodness-of-fit between observed and simulated soil water using root mean square error (RMSE) of the continuous cropping treatments during periods of summer fallow (SF) or growing season (GS) (RMSE as a percentage of the mean is shown in parentheses).

\begin{tabular}{|c|c|c|c|c|c|c|c|c|}
\hline Site & Parameters Used & Overall & $\begin{array}{c}2002 \\
\mathrm{SF}\end{array}$ & $\begin{array}{c}2002 \\
\text { GS }\end{array}$ & $\begin{array}{c}2002-2003 \\
\text { SF }\end{array}$ & $\begin{array}{c}2003 \\
\text { GS }\end{array}$ & $\begin{array}{c}2003-2004 \\
\text { SF }\end{array}$ & $\begin{array}{c}2004 \\
\text { GS }\end{array}$ \\
\hline \multirow[t]{4}{*}{ Waikerie } & $\theta_{\mathrm{vCLL}} / \theta_{\mathrm{vDUL}}$ & $5.5(7)$ & $4.8(7)$ & $6.7(10)$ & $3.8(4)$ & $5.0(6)$ & $6.6(9)$ & $6.6(9)$ \\
\hline & $\theta_{\mathrm{v} 1500} / \theta_{\mathrm{vDUL}}$ & $6.6(9)$ & $6.8(10)$ & $8.2(12)$ & $4.8(6)$ & $8.2(10)$ & $4.8(6)$ & $4.8(6)$ \\
\hline & $\theta_{\mathrm{vCLL}} / \theta_{\mathrm{v} 10}$ & $7.9(11)$ & $8.7(14)$ & $7.8(12)$ & $5.4(5)$ & $10.0(12)$ & $8.2(12)$ & $8.1(11)$ \\
\hline & $\theta_{\mathrm{v} 1500} / \theta_{\mathrm{v} 10}$ & $10.7(14)$ & $12.5(18)$ & $10.2(14)$ & $7.4(9)$ & $12.6(15)$ & $10.9(15)$ & $10.9(15)$ \\
\hline \multirow[t]{4}{*}{ Kerribee } & $\theta_{\mathrm{vCLL}} / \theta_{\mathrm{vDUL}}$ & $10.3(9)$ & - & $9.8(9)$ & $10.8(8)$ & $5.3(4)$ & $8.8(8)$ & $13.5(12)$ \\
\hline & $\theta_{\mathrm{v} 1500} / \theta_{\mathrm{vDUL}}$ & $12.7(11)$ & - & $14.7(14)$ & $14.9(12)$ & $6.7(6)$ & $11.1(10)$ & $11.3(10)$ \\
\hline & $\theta_{\mathrm{vCLL}} / \theta_{\mathrm{v} 10}$ & $17.7(15)$ & - & $8.8(8)$ & $10.1(8)$ & $14.1(10)$ & $17.1(14)$ & $32.9(30)$ \\
\hline & $\theta_{\mathrm{v} 1500} / \theta_{\mathrm{v} 10}$ & $14.3(12)$ & - & $14.0(13)$ & $11.3(9)$ & $11.0(9)$ & $9.8(8)$ & $25.5(22)$ \\
\hline
\end{tabular}

bined layers and underestimation in the deepest combined layer occurred again after the large rainfall events in December 2004, probably indicating that water movement to deeper layers, e.g., via macropore flow, might not be well simulated by the model. Of critical importance were the predictions of soil moisture near sowing events, as this information is used for decision-making by farmers and managers. Comparing the soil water measurements near the sowing events that occurred on 24 June 2002, 29 May 2003, and 4 June 2004, the simulated PAW (0-1 m) values were within $7 \mathrm{~mm}$ of the measured data. In the period of crop growth, there was a tendency for modeled soil moisture to be consistently below the measured values in the three seasons, although this difference was less than $10 \mathrm{~mm}$. For the Waikerie site, simulated soil moisture at sowing and harvest was predicted with an RMSE of $6.7 \mathrm{~mm}$ (fig. 3).

At Kerribee, the dataset represents the continuous cereal wheat-wheat-wheat treatment in 2002, 2003, and 2004. Because the FDR data for the top layer were unreliable during the first two months of measurement, this section of data was discarded. It is common for such soil water sensors to need a settling-in period. In the combined top layers $(0-0.2 \mathrm{~m}$; fig. 2a) rainfall events resulted in much higher peaks in soil water than the simulated data, with a decrease back to values close to measured values within one day (or one model time step). In a few cases (e.g., 30 May to 31 July 2004), modeled soil water data remained above the measured data (figs. $2 \mathrm{a}$ and $2 \mathrm{~b}$.). The deepest combined layers were modeled poorly and did not represent the increase in soil water represented by the measured data (fig. 2c). For soil water content in the profile $(0-1.0 \mathrm{~m})$, the simulated and observed data were closely aligned during most of the measurement period, and combining the layers averaged out the errors of overpredicting soil water in the $0-0.4 \mathrm{~m}$ depth and underpredicting in the deeper layers. The simulated soil moisture at sowing and harvest was predicted with an RMSE of $10.8 \mathrm{~mm}$ (fig. 3).

\section{Measured versus Modeled Yield}

By simulating all seasons when wheat was grown, the comparison between predicted and observed wheat grain yields was reasonable, with an RMSE of $0.43 \mathrm{t} \mathrm{ha}^{-1}$ representing $39 \%$ of the mean of all yields $(n=46)$ (fig. 4$)$. However, this would be close to the limits of acceptability to farmers in low-rainfall regions, where yields are often below $1.5 \mathrm{t} \mathrm{ha}^{-1}$ and simulation errors must be small $\left(<0.5 \mathrm{t} \mathrm{ha}^{-1}\right)$. The agreement between observed and predicted canola yields was poor for two of the ten canola crops, and therefore the RMSE was $0.42 \mathrm{t} \mathrm{ha}^{-1}$ (average yield $0.47 \mathrm{t} \mathrm{ha}^{-1}$ ). Given that the canola yielded $<1 \mathrm{t} \mathrm{ha}^{-1}$ for all but one crop, new data are required to parameterize these low-rainfall canola varieties.

Using the outputs from the 109 years of continuous wheat simulations for Waikerie, the effect of sowing date and PAW at sowing is stark (fig. 5). A late sowing opportunity coinciding with low PAW at sowing resulted in $75 \%$ of yields falling in the lowest yield tercile. Conversely, early sowing with high PAW at sowing resulted in more than $50 \%$ of yields falling in the highest yield tercile.

\section{DISCUSSION}

\section{Plant-Available Soil Water Capacity}

Determining the limits of plant-available water is crucial for crop modeling, particularly in semi-arid environments where water often limits attainable yield. Reliable prediction of crop performance with crop models requires good estimates of PAWC. Aside from their use in crop modeling, estimates of PAWC can be related in simpler regression models to potential yields (Lawes et al., 2009; Rab et al., 2009). Therefore, these estimates can be used in precision farming approaches to identify management zones within a field with low and high potential yield (Hoffmann et al., 2015; Whitbread et al., 2008).

\section{Estimation of Upper Limits of Soil Water Content}

In this study, we found that $\theta_{\mathrm{v} 10}$ was generally much greater than FDR $\theta_{\mathrm{vMax}}$ at Waikerie and far below FDR $\theta_{\mathrm{vMax}}$ in the top layers at Kerribee. Therefore, $\theta_{\mathrm{vDUL}}$ was used as the default for the upper limit in modeling calculations. This also fits with the usual procedure, as outlined by Dalgliesh and Foale (1998). Gijsman et al. (2002) and Diekkrüger (1990) suggested that, due to small sample sizes (often $<100 \mathrm{~cm}^{-3}$ ), laboratory-measured upper limits cannot realistically represent the soil structure, which has a strong influence on the water retention capacity of a soil. Historically, there were discussions on appropriate suction plate settings ( 10 or $33 \mathrm{kPa}$ ) for predicting the field capacity of sandy soils or whether a static term generally lacks the variability that is needed to determine the upper limit (Ratliff et al., 1983; Baumer and Rice, 1988). Gijsman et al. (2002) also showed differing estimates for field and laboratory-measured lower and upper limits of PAW and suggested that laboratory methods were often unreliable. In our study, and in line with the review findings of Gijsman et al. (2002), the use of laboratory $\left(\theta_{\mathrm{v} 10}\right)$ rather than field $\left(\theta_{\mathrm{vDUL}}\right)$ values led to in- 

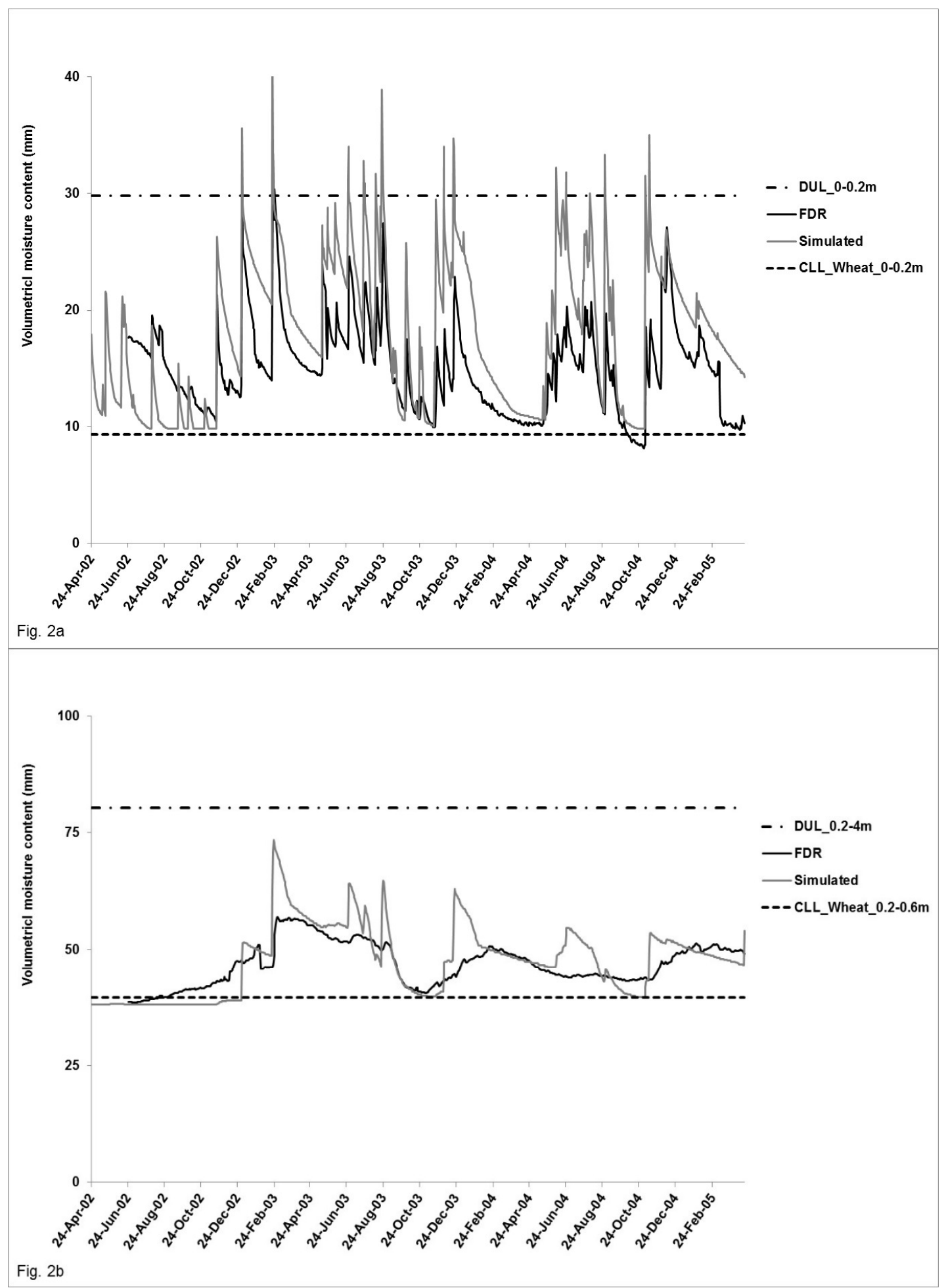

Figure 2. Measured and simulated water content ( $\mathrm{mm}$ ) calculated for the (a) 0-0.2 m layer and (b) 0.2-0.6 m layer for Kerribee treatment 5 (wheatwheat-wheat) during 2002 to 2005.

creased model error (table 5). Overestimating DUL in the surface layers increases the loss of water due to soil evaporation, with this effect particularly observable during the fallow period in the summer months, when evaporation plays a major role in the water cycle (figs. 1a and 2a).

\section{Estimation of Lower Limits of Soil Water Content}

A growing body of literature shows that chemical (i.e., high salt and boron concentrations) and/or physical (rock or lateritic layers) subsoil constraints strongly influence water uptake by crops, which has to be accounted for in crop model parameterization (Hochman et al., 2001; Dang et al., 2006; Nuttall et al., 2005; Rodriguez et al., 2006). Sadras et al. (2003), among others, suggested that, for modeling purposes, dealing with such constraints requires considering the 


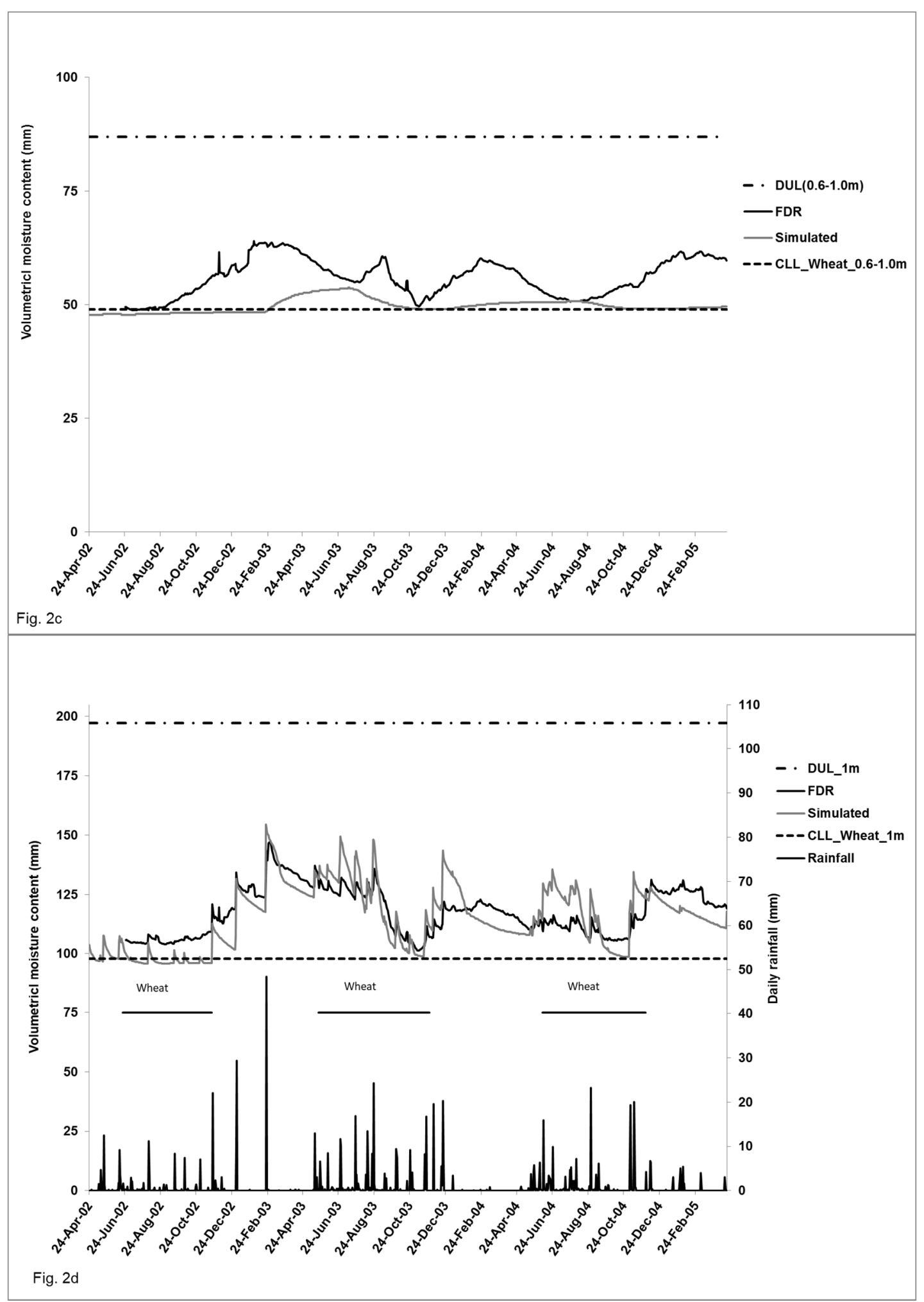

Figure 2 (continued). Measured and simulated water content $(\mathrm{mm})$ calculated for the (c) 0.6-1.0 $\mathrm{m}$ layer and (d) 0-1.0 $\mathrm{m}$ profile for Kerribee treatment 5 (wheat-wheat-wheat) during 2002 to 2005. Figure 2d also displays daily rainfall data, and the horizontal lines represent the growing season (sowing to harvest) for each crop.

lower limit of PAWC as a crop-dependent term and not only a soil-specific term. It is well known that crops differ in their ability to extract water from the soil, e.g., under conditions of high salt concentration. Similar to the previous section, field estimates of $\theta_{\mathrm{vLL}}$ rather than laboratory-measured $\theta_{\mathrm{v} 1500}$ resulted in the lowest error for the prediction of soil water content (table 5), and notably the combination of field measurements of DUL and CLL was optimal. For sites where subsoil constraints are greater, the differences between estimates of CLL using a field or laboratory method will be 


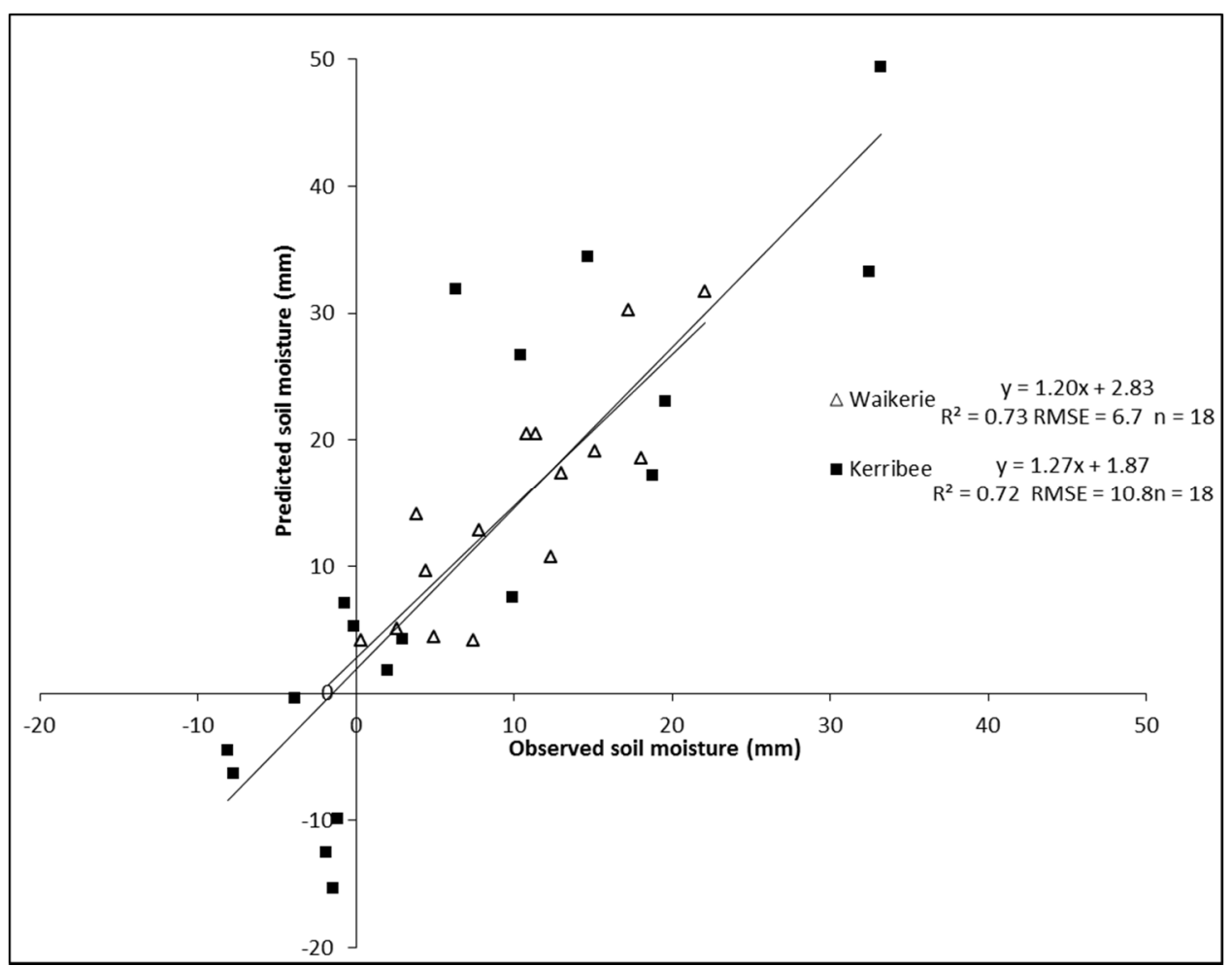

Figure 3. Measured versus simulated soil water content $(\mathrm{mm})$ for the $0-1.0 \mathrm{~m}$ profile based on field-measured soil water limits $\left(\theta_{\mathrm{vDDL}}\right.$ and $\theta_{\mathrm{vLL}}$ wheat) at sowing and harvest for Waikerie and Kerribee (2002, 2003, and 2004).

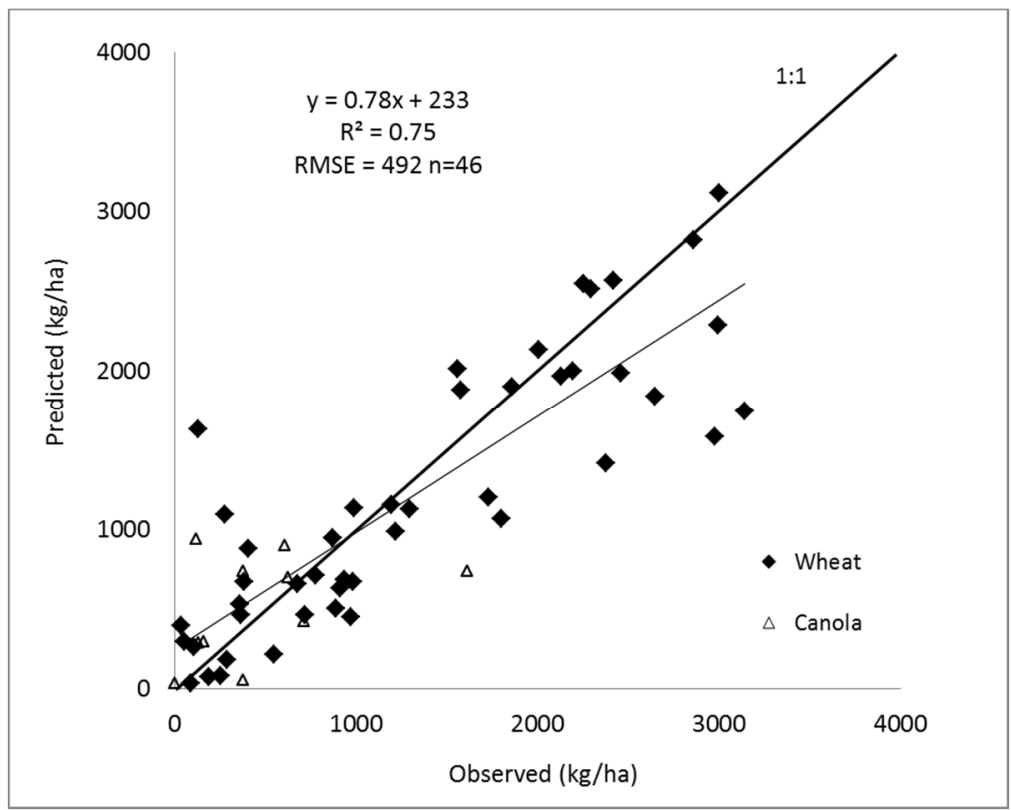

Figure 4. Measured versus predicted wheat $(n=46)$ and canola $(n=8)$ grain yields for all treatments in the Waikerie and Kerribee trials $(W h i t-$ bread et al., 2015).

larger. Exploiting variations in soil properties, Hochman et al. (2007) found a good relationship between measured ESP and $\theta_{\mathrm{vLL}}$ on a Vertosol soil. Such relationships may be a way of reducing the sampling intensity required for estimation of water limits.

\section{MEASUREMENT AND SIMULATION} OF SOIL WATER CONTENT

Realistic simulation of soil water dynamics is a prerequisite for successful modeling of the growth behavior of crops, particularly in areas with low rainfall. Despite the need for good validation of model results, there is a lack of long-term 


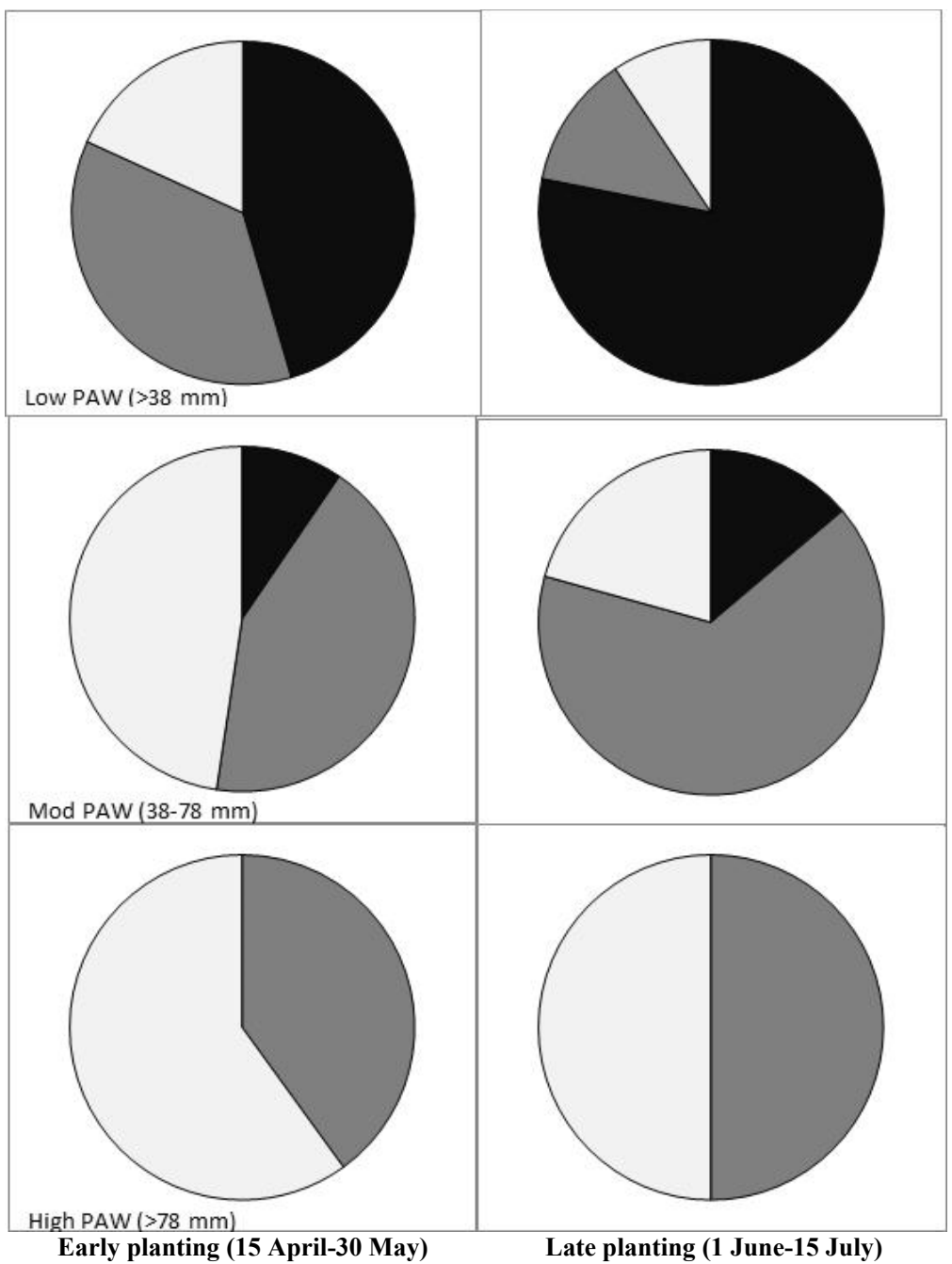

Figure 5. Wheat yield outcomes for simulated scenarios of soil water content at sowing and early or late planting dates. The color indicates the proportion of years with yields in each tercile: black is the lowest, gray is the middle, and white is the highest yielding tercile.

studies on soil moisture dynamics for semi-arid regions. For example, Yunusa et al. (2004) presented validations based on single days, while Verburg et al. (2007) presented intermittently monitored soil water contents over several seasons. Therefore, the continuously measured datasets used in this study offer a unique opportunity to test the soil water balance models within an important cropping system. Of critical importance for management was the accurate prediction of soil moisture values near sowing events (e.g., 24 June 2002, 29 May 2003, 4 June 2004), which were within $7 \mathrm{~mm}$ of the measured data (figs. 1d and 2d). In the periods during crop growth, there was a tendency for the modeled soil moisture to be consistently below the measured data in the three seasons, although this difference was always $<10 \mathrm{~mm}$.

The prediction of wheat yields with an RMSE of $0.43 t$ ha $^{-1}$ (fig. 4) is considered to be close to the limits acceptable to farmers in low-rainfall regions, where yields are often below $1.5 \mathrm{tha}^{-1}$ and simulation errors must be $<0.5 \mathrm{tha}^{-1}$. The level of error reported in this article is comparable to that reported by Hochman et al. (2001, 2007) for validations based on large numbers of on-farm measurements.

The simulation experiment was presented as an example of how a validated and robust crop-soil modeling framework might be usefully applied to devising management strategies. Strong swings in the probabilities of different yield outcomes were observed based on changes in opening PAW and seeding opportunity: Even with low PAW $(<38 \mathrm{~mm})$, the simulation results suggested that relatively moderate yields can be achieved in more than half of the seasons when the sowing date is early enough. Planting late with low PAW in more than $75 \%$ of all seasons resulted in very low yields and crop failures. However, with high PAW of $>78 \mathrm{~mm}$, the farmers achieved moderate to good yields in all seasons despite the planting date. To provide realistic estimations in a simulation scenario for such an environment, the model must be able to simulate initial sowing conditions in a reasonable range, as shown above. The results of this study show that the model may have a key role in establishing more robust trigger points for cropping decisions in unreliable cropping environments, as first suggested by Mudge and Whitbread (2010).

\section{CONCLUSION}

In this study, we found that field-measured estimates of the lower and upper limits of PAW were more suitable for 
parameterization of the APSIM model than values derived from common laboratory methods. APSIM was able to simulate the soil moisture dynamics over three-year rotations with predicted soil water within $7 \mathrm{~mm}$ (PAWC 64 to $99 \mathrm{~mm}$ ) of the measured data across all sowing events and rotations. The errors associated with simulating wheat grain production $\left(\mathrm{RMSE}=492 \mathrm{~kg} \mathrm{ha}^{-1}\right.$ ) were only marginally smaller than that of other field studies that derived soil water limits from less detailed methods. This study showed that using field-derived data of soil water limits and soil-specific settings for determining soil evaporation and water redistribution enables APSIM to be confidently applied to managing climate risk in low-rainfall environments. One application, for example, is the establishment of robust trigger points for cropping decisions depending on PAW at critical times in the cropping cycle.

\section{ACKNOWLEDGEMENTS}

We thank Mallee Sustainable Farming, Inc., and collaborating farmers Allen Buckley and Jim Maynard for their assistance and the Grain Research and Development Corporation for financial support. In particular, Dr. V. V. S. R. Gupta and the late David Roget are acknowledged for their pivotal roles in initiating the long-term trials described in this article. Dr. Ben Jones of Mallee Focus is acknowledged for database compilation of the trial management information and results. The staff time of A. M. Whitbread has been funded through the CGIAR Research Program on Water, Land, and Ecosystems (WLE) and the CGIAR Research Program on Climate Change, Agriculture, and Food Security (CCAFS).

\section{REFERENCES}

Baumer, O. W., \& Rice, J. W. (1988). Methods to predict soil input data for DRAINMOD. ASAE Paper No. 882564. St. Joseph, MI: ASAE.

Carberry, P. S., Hochman, Z., Hunt, J. R., Dalgliesh, N. P., McCown, R. L., Whish, J. P. M., ... van Rees, H. (2009). Reinventing model-based decision support with Australian dryland farmers: 3. Relevance of APSIM to commercial crops. Crop Pasture Sci., 60(11), 1044-1056. https://doi.org/10.1071/CP09052

Chan, K. Y., Heenan, D. P., \& So, H. B. (2003). Sequestration of carbon and changes in soil quality under conservation tillage on light-textured soils in Australia: A review. Australian J. Exp. Agric., 43(4), 325-334. https://doi.org/10.1071/EA02077

Connor, D. J. (2004). Designing cropping systems for efficient use of limited water in southern Australia. European J. Agron., 21(4), 419-431. https://doi.org/10.1016/j.eja.2004.07.004

Dalgliesh, N., \& Foale, M. (1998). Soil matters: Monitoring soil water and nutrients in dryland farming. Toowoomba, Australia: Agricultural Production Systems Research Unit.

Dang, Y. P., Routley, R. B., McDonald, M. D., Dalal, R. C. E., Singh, D. K. B., Orange, D. A., \& Mann, M. B. (2006). Subsoil constraints in Vertosols: Crop water use, nutrient concentration, and grain yields of bread wheat, durum wheat, barley, chickpea, and canola. Australian J. Agric. Res., 57(9), 983-998. https://doi.org/10.1071/AR05268

Dean, T. J., Bell, J. P., \& Baty, A. J. (1987). Soil moisture measurement by an improved capacitance technique: Part I. Sensor design and performance. J. Hydrol., 93(1), 67-78. https://doi.org/10.1016/0022-1694(87)90194-6
Diekkruger, B. (1990). Calculation of soil properties for different scales. Proc. 14th Intl. Congress of Soil Science (pp. 190-195). Vienna, Austria: International Society of Soil Science.

Gijsman, A. J., Jagtap, S. S., \& Jones, J. W. (2002). Wading through a swamp of complete confusion: How to choose a method for estimating soil water retention parameters for crop models. European J. Agron., 18(1), 77-106. https://doi.org/10.1016/S1161-0301(02)00098-9

Hochman, Z., Dalgliesh, N. P., \& Bell, K. L. (2001). Contributions of soil and crop factors to plant-available soil water capacity of annual crops on black and grey vertosols. Australian J. Agric. Res., 52(10), 955-961. https://doi.org/10.1071/AR01004

Hochman, Z., Dang, Y. P., Schwenke, G. D., Dalgliesh, N. P., Routley, R., McDonald, M., ... Poulton, P. L. (2007). Simulating the effects of saline and sodic subsoils on wheat crops growing on vertosols. Australian J. Agric. Res., 58(8), 802-810. https://doi.org/10.1071/AR06365

Hoffmann, M. P., Llewellyn, R. S., Davoren, C. W., \& Whitbread, A. M. (2017). Assessing the potential for zone-specific management of cereals in low-rainfall southeastern Australia: Combining on-farm results and simulation analysis. J. Agron. Crop Sci., 203(1), 14-28. https://doi.org/10.1111/jac.12159

Holzworth, D. P., Huth, N. I., deVoil, P. G., Zurcher, E. J., Herrmann, N. I., McLean, G., ... Keating, B. A. (2014). APSIM: Evolution towards a new generation of agricultural systems simulation. Environ. Model. Softw., 62, 327-350. https://doi.org/10.1016/j.envsoft.2014.07.009

Hunt, J. R., \& Kirkegaard, J. A. (2011). Re-evaluating the contribution of summer fallow rain to wheat yield in southern Australia. Crop Pasture Sci., 62(11), 915-929. https://doi.org/10.1071/CP11268

Hunt, J. R., Browne, C., McBeath, T. M., Verburg, K., Craig, S., \& Whitbread, A. M. (2013). Summer fallow weed control and residue management impacts on winter crop yield though soil water and $\mathrm{N}$ accumulation in a winter-dominant, low-rainfall region of southern Australia. Crop Pasture Sci., 64(9), 922-934. https://doi.org/10.1071/CP13237

Hutton, J. T. (1955). A method of particle size analysis of soils. Report No. 11/55. Black Mountain, Australia: CSIRO, Division of Soils.

Isbell, R. F. (1996). The Australian soil classification. Clayton South, Australia: CSIRO Publishing.

Jones, J. W., Hoogenboom, G., Porter, C. H., Boote, K. J., Batchelor, W. D., Hunt, L. A., ... Ritchie, J. T. (2003). The DSSAT cropping system model. European J. Agron., 18(3), 235-265. https://doi.org/10.1016/S1161-0301(02)00107-7

Keating, B. A., Carberry, P. S., Hammer, G. L., Probert, M. E., Robertson, M. J., Holzworth, D., ... Smith, C. J. (2003). An overview of APSIM, a model designed for farming systems simulation. European J. Agron., 18(3), 267-288. https://doi.org/10.1016/S1161-0301(02)00108-9

Lawes, R. A., Oliver, Y. M., \& Robertson, M. J. (2009). Integrating the effects of climate and plant-available soil water holding capacity on wheat yield. Field Crops Res., 113(3), 297-305. https://doi.org/10.1016/j.fcr.2009.06.008

Leys, J., \& McTainsh, G. (1994). Soil loss and nutrient decline by wind erosion: Cause for concern. Australian J. Soil Water Cons., 7(3), 30-35.

Llewellyn, R. S., D’Emden, F. H., \& Kuehne, G. (2012). Extensive use of no-tillage in grain growing regions of Australia. Field Crops Res., 132, 204-212. https://doi.org/10.1016/j.fcr.2012.03.013

Mudge, B., \& Whitbread, A. M. (2010). Making better decisions about crop rotations in low-rainfall environments: Should stored moisture and the timing of the seeding opportunity influence this decision? In H. Dove, \& R. Culvenor (Ed.), Proc. 15th 
Australian Agronomy Conf. Australian Society of Agronomy.

Nuttall, J. G. A., Armstrong, R. D. A., \& Connor, D. J. B. (2005).

The effect of boron tolerance, deep ripping with gypsum, and water supply on subsoil water extraction of cereals on an alkaline soil. Australian J. Agric. Res., 56(2), 113-122. https://doi.org/10.1071/AR04183

Priestley, C. H. B., \& Taylor, R. J. (1972). On the assessment of surface heat flux and evaporation using large-scale parameters. Monthly Weather Rev., 100(2), 81-92. https://doi.org/10.1175/15200493(1972) $100<0081$ :otaosh $>2.3 . c 0 ; 2$

Probert, M. E., Dimes, J. P., Keating, B. A., Dalal, R. C., \& Strong, W. M. (1998). APSIM's water and nitrogen modules and simulation of the dynamics of water and nitrogen in fallow systems. Agric. Syst., 56(1), 1-28. https://doi.org/10.1016/S0308-521X(97)00028-0

Rab, M. A., Fisher, P. D., Armstrong, R. D., Abuzar, M., Robinson, N. J., \& Chandra, S. (2009). Advances in precision agriculture in southeastern Australia: IV. Spatial variability in plant-available water capacity of soil and its relationship with yield in sitespecific management zones. Crop Pasture Sci., 60(9), 885-900. https://doi.org/10.1071/CP08350

Rallison, R. E. (1980). Origin and evolution of the SCS runoff equation. Proc. Symp. on Watershed Management (pp. $912-$ 924). Reston, VA: ASCE.

Ratliff, L. F., Ritchie, J. T., \& Cassel, D. K. (1983). Field-measured limits of soil water availability as related to laboratory-measured properties. SSSA J., 47(4), 770-775. https://doi.org/10.2136/sssaj1983.03615995004700040032x

Rayment, G. E., \& Higginson, F. R. (1992). Australian laboratory handbook of soil and water chemical methods. Melbourne, Australia: Inkata Press.

Rayment, G. E., \& Lyons, D. J. (2011). Soil chemical methods: Australasia. Clayton South, Australia: CSIRO Publishing.

Ritchie, J. T. (1972a). Soil water availability. Plant Soil, 58(1), 327338. https://doi.org/10.1007/bf02180061

Ritchie, J. T. (1972b). Model for predicting evaporation from a row crop with incomplete cover. Water Resour. Res., 8(5), 12041213. https://doi.org/10.1029/WR008i005p01204

Ritchie, J. T., \& Crum, J. (1989). Converting soil survey characterization data into IBSNAT crop model input. In J. Bouma, \& A. K. Bregt (Ed.), Proc. ISSS Symp. on Land Qualities in Space and Time. Vienna, Austria: International Society of Soil Science.

Ritchie, J. T., Gerakis, A., \& Suleiman, A. (1999). Simple model to estimate field-measured soilwater limits. Trans. ASAE, 42(6), 1609-1614. https://doi.org/10.13031/2013.13326

Rodriguez, D., Nuttall, J., Sadras, V. O., van Rees, H., \& Armstrong, R. (2006). Impact of subsoil constraints on wheat yield and gross margin on fine-textured soils of the southern Victorian Mallee. Australian J. Agric. Res., 57(3), 355-365. https://doi.org/10.1071/AR04133

Sadras, V. O., \& Angus, J. F. (2006). Benchmarking water-use efficiency of rainfed wheat in dry environments. Australian $J$. Agric. Res., 57(8), 847-856. https://doi.org/10.1071/AR05359

Sadras, V. O., Baldock, J., Roget, D. K., \& Rodriguez, D. (2003). Measuring and modeling yield and water budget components of wheat crops in coarse-textured soils with chemical constraints. Field Crops Res., 84(3), 241-260. https://doi.org/10.1016/S0378-4290(03)00093-5

Sadras, V. O., Roget, D. K., \& O’Leary, G. J. (2002). On-farm assessment of environmental and management constraints to wheat yield and efficiency in the use of rainfall in the Mallee. Australian J. Agric. Res., 53(5), 587-598. https://doi.org/10.1071/AR01150

USDA. (1982). Particle size analyses: Procedures for collecting soil samples and methods of analysis for soil survey. Soil Survey Investigation Report No. 1. Washington, DC: USDA Soil Conservation Service.

Vanstone, V. A., Hollaway, G. J., \& Stirling, G. R. (2008). Managing nematode pests in the southern and western regions of the Australian cereal industry: Continuing progress in a challenging environment. Australasian Plant Pathol., 37(3), 220-234. https://doi.org/10.1071/ap08020

Verburg, K., Bond, W. J., Hirth, J. R., \& Ridley, A. M. (2007). Lucerne in crop rotations on the Riverine Plains: 3. Model evaluation and simulation analyses. Australian J. Agric. Res., 58(12), 1129-1141. https://doi.org/10.1071/AR07133

Whitbread, A. M., Davoren, C. W., Gupta, V. V. S. R., Llewellyn, R., \& Roget, D. K. (2015). Long-term cropping system studies support intensive and responsive cropping systems in the lowrainfall Australian Mallee. Crop Pasture Sci., 66(6), 553-565. https://doi.org/10.1071/CP14136

Whitbread, A. M., Robertson, M. J., Carberry, P. S., \& Dimes, J. P. (2010). How farming systems simulation can aid the development of more sustainable smallholder farming systems in southern Africa. European J. Agron., 32(1), 51-58. https://doi.org/10.1016/j.eja.2009.05.004

Whitbread, A. M., Llewellyn, R., Gobbett, D., \& Davoren, B. (2008). EM38 and crop-soil simulation modeling can identify differences in potential crop performance on typical soil zones in the Mallee. Proc. 14th Australian Agronomy Conf. Australian Society of Agronomy.

Yunusa, I. A. M., Bellotti, W. D., Moore, A. D., Probert, M. E., Baldock, J. A., \& Miyan, S. M. (2004). An exploratory evaluation of APSIM to simulate growth and yield processes for winter cereals in rotation systems in South Australia. Australian J. Exp. Agric., 44(8), 787-800. https://doi.org/10.1071/EA03121 